\title{
Effect of proprioceptive training on balance in patients with chronic neck pain
}

\author{
Kronik boyun ağrılı hastalarda proprioseptif eğitimin denge üzerine etkisi
}

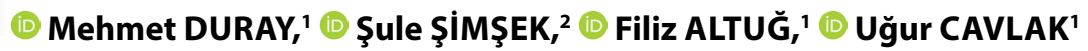

\begin{abstract}
Summary
Objectives: The aim of this randomized controlled study was to investigate the effect of proprioceptive training on balance in patients with chronic neck pain (CNP).

Methods: Forty patients participating in the study were randomly divided into study and control groups. Both of the groups underwent conventional physical therapy; additionally, the study group was rehabilitated with gaze direction recognition exercise (GDRE) for proprioceptive training. Exercises were performed during 3 weeks with five sessions per week. Pain intensity [visual analog scale (VAS)], neck disability [Neck Disability Index (NDI)], and balance [four step square test (FSST), single leg balance test (SLBT) with eyes opened and closed] assessments were conducted in the patients before and after the treatment and 3 weeks after the last session.
\end{abstract}

Results: No differences were observed between the groups in terms of pre-treatment measurements. There was a statistically significant decrease in VAS scores in both groups compared with pre-treatment conditions $(p<0.05)$. In addition, whereas a statistically significant improvement in the study group's NDI, FSST, and SLBT with eyes opened and closed scores was observed after the treatment, pre- and post-treatment results were similar in the control group ( $p>0.05)$.

Conclusion: Proprioceptive training should be included in physiotherapy programs to improve balance; it decreases the disability level in patients with CNP.

Keywords: Balance; neck pain; proprioception.

\section{Özet}

Amaç: Bu randomize kontrollü araştırmanın amacı kronik boyun ağrısına (KBA) sahip hastalarda proprioseptif eğitimin denge üzerine etkisini incelemektir.

Gereç ve Yöntem: Çalışmaya katılan 40 hasta randomize olarak çalışma ve kontrol gruplarına ayrıldı. Her iki gruba da Konvansiyonel Fizik Tedavi uygulanırken, çalışma grubu proprioseptif eğitim için ek olarak bakış yönü tanıma egzersizi (BYTE) ile tedavi edildi. Hastalara, tedavinin başlangıcında, tedavi bitiminde ve son seanstan 3 hafta sonra ağrı şiddeti [Görsel Analog Skalası (GAS)], boyun özür seviyesi [Boyun Özür İndeksi (BÖi)] ve denge [Dört Adım Kare Testi (DAKT), gözler açık ve kapalı tek ayak denge testi (TADT)] değerlendirmeleri yapıldı.

Bulgular: Tedavi öncesi değerlendirmeler bakımından gruplar arasında fark bulunmadı. Tedavi öncesi ile karşılaştırıldığında her iki grubun GAS skorlarında istatistiksel olarak anlamlı azalma vardı $(p<0.05)$. Ek olarak çalışma grubunun BÖi, DAKT ve gözler açık ve kapalı TADT skorlarında istatistiksel olarak anlamlı gelişme olduğunu gözlemlenirken, kontrol grubunda tedavi öncesi ve sonrası sonuçlar benzerdi.

Sonuç: Sonuçlarımıza göre, KBA' na sahip hastalarda dengeyi geliştirmek ve özür seviyesini azaltmak için fizyoterapi programları proprioseptif eğitimi içermelidir.

Anahtar sözcükler: Boyun ağrısı; denge; pozisyon duyusu.

\section{Introduction}

Chronic neck pain (CNP) is one of the most common lifelong musculoskeletal diseases with a changing prevalence of $43 \%-66.7 \%$ in adults. ${ }^{[1]}$ Neck problems lead to functional loss, disability, and decrease in the quality of life as well as pain. In addition to medical and surgical treatment, physical rehabilitation including therapeutic exercises has an important function in the treatment of CNP. Positive effects of these exercises on neurologic, immuno-

'Department of Physical Therapy and Rehabilitation,Pamukkale University, Denizli, Turkey

${ }^{2}$ Department of Physical Therapy and Rehabilitation, Denizli State Hospital, Denizli, Turkey

Submitted (Başvuru tarihi) 10.10.2017 Accepted after revision (Düzeltme sonrası kabul tarihi) 02.03.2018 Available online date (Online yayımlanma tarihi) 28.06.2018

Correspondence: Dr. Filiz Altuğ. Pamukkale Üniversitesifizik Tedavi ve Rehabilitasyon Yorektörlük Binası Giriş Katı, Kınıkı Kampusu Kınıklı, 20100 Denizli, Turkey.

Phone: +90 - 535 -5625146 e-mail: fkural@pau.edu.tr

(c) 2018 Turkish Society of Algology 
logic, cardiovascular, and musculoskeletal systems have been observed in patients with CNP. ${ }^{[2]}$

In the conventional treatment of CNP, range of motion (ROM) exercises for the neck and upper extremity; stretching; strengthening; static and dynamic stabilization exercises; and traditional approaches, such as mobilization and electro-therapy applications, are commonly used. ${ }^{[2-4]}$ However, CNP is a multi-factorial phenomenon. As a result of the changing mechanical properties of cervical structures, including ligaments, muscles, and bones, flexion-relaxation phenomenon and erector spinae muscle activation are responsible for proprioception sense disturb. ${ }^{[5]}$ While sensorimotor control decreases, repositioning errors increase in cervical joints due to damage of cervical proprioceptive inputs and sensorimotor integration. All these changes, which result in the loss of proprioceptive skills that are an important part of balance, lead to sensorimotor defects, muscle inhibition, muscle atrophy, and muscle fatigue. Therefore, the treatment for sensorimotor problems should be included balance training, such as cervical region proprioceptive exercises, in addition to conventional treatment. It has been reported that proprioceptive training improves proprioceptive acuity and is effective in the reduction of errors in joint position. ${ }^{[6-8]}$

Proprioception is important in the treatment of all neck pain problems. However, it is not clear which physical therapy method leads to improved balance in the presence of neck pain. Therefore, this study aimed to investigate the effect of gaze direction recognition exercise (GDRE) used for proprioceptive improvement on balance in patients with CNP.

\section{Material and Methods}

\section{Participants}

This trial included volunteers aged $25-55$ years with CNP that persisted for at least 3 months and who had minimum $10 \%$ limitation in the ROM of neck rotation. Patients with acute CNP; pain due to a specific cause (e.g., fracture, spondylolisthesis, disc herniation, and cervical stenosis); neurological (e.g., stroke), endocrinological (e.g., diabetes mellitus), orthopedic (e.g., knee osteoarthritis), or other systemic diseases that may affect balance; a history of an orthopedic surgical procedure for CNP; and congenital anomalies, as well as pregnants, were excluded.
It was calculated by a power analysis program that $90 \%$ power and $95 \%$ confidence will be obtained if 40 people are included in the study. In total, 150 participants were scanned between January and March 2016, and 55 participants who met our criteria were recruited. The study was finalized with 40 participants who were diagnosed and enrolled in the rehabilitation program by a physiatrist (Fig. 1). Neurologic exam, ROM test, reflex tests, and imaging methods such as X-rays and MRI were used for distinctive diagnosis. By selection from closed envelopes, the participants were randomly separated into two groups, the GRDE (study group) and control groups; each group comprised 20 patients. The study was approved by the Ethics and Human Research committee. All the patients gave their written informed consent.

\section{Outcomes and measurements}

After participants' demographics (age, gender, height, body weight, and medical history) were recorded, and assessment of the neck pain intensities, neck disability levels, and balance was performed. All the assessments were performed three times for each participant as pre-treatment, immediately after the treatment, and 3 weeks after the last session by the same physiotherapist.

Pain intensity: Pain intensity at rest was evaluated using a 10-centimeter visual analog scale (VAS) before and after the treatment. ${ }^{[2]}$

Neck disability level: This level was evaluated using the neck disability index (NDI). Turkish validity and reliability of this questionnaire were tested by Aslan and Karaduman in 2008. This scale comprises 10 questions. NDI tests how much neck pain affects the ability in daily work. Total points are scored between 0 (no disability) and 100 (heavy disability). ${ }^{[9]}$

Four step square tests (FSST): This test is used to test dynamic balance. Four squares were formed by placing two canes on a smooth ground. At the beginning of the test, the participant standing on the square number 1 as toward the square number 2 was told to step every square successively (2- 3- 41- 4- 3-2-1) without touching the canes, and his/her feet should touch the ground. (Necessitates the participant to step forward, backward, right, and left). 


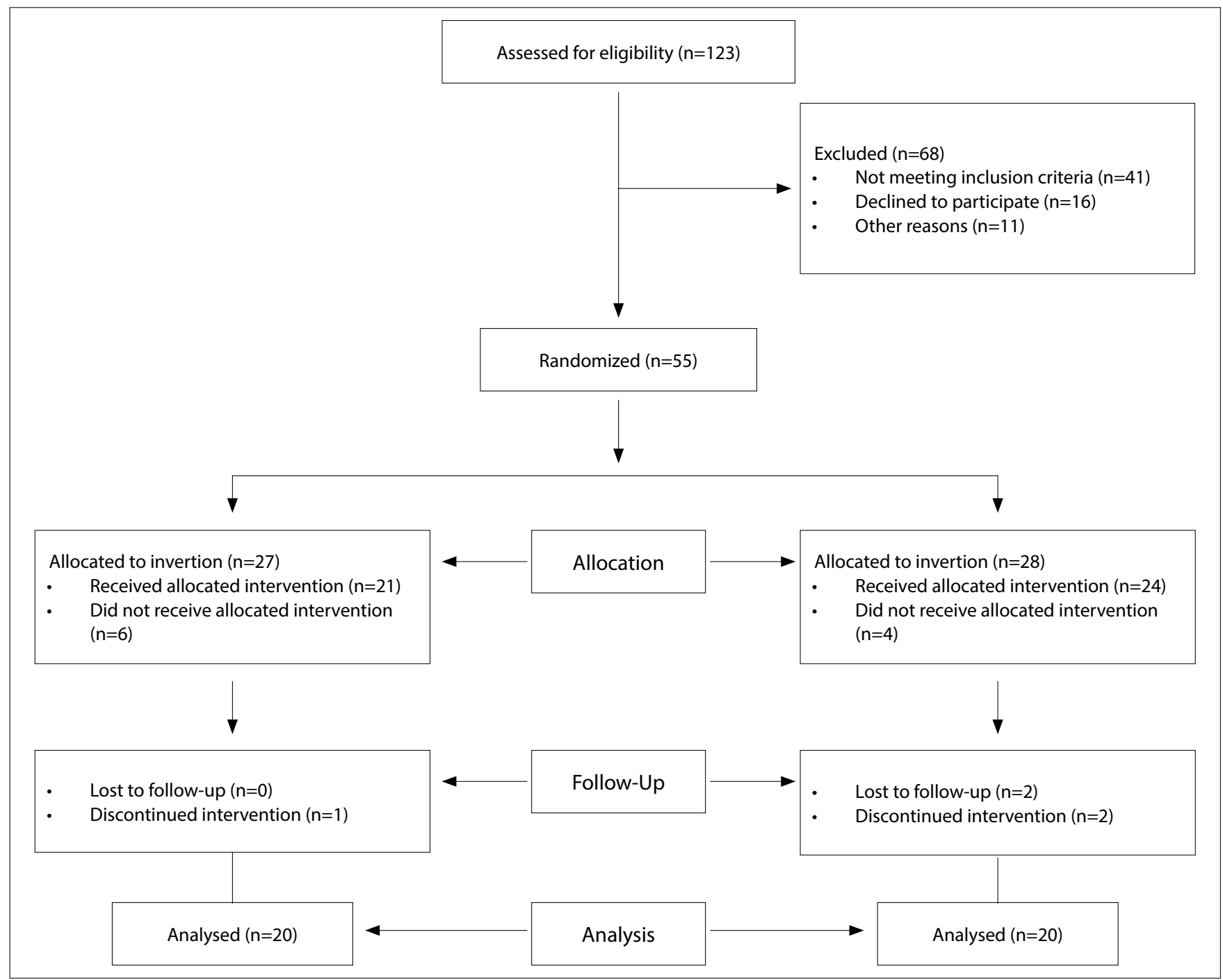

Figure 1. Participant flow and retention.

The physical therapist demonstrated the test, and the patient was allowed to practice the pattern to learn the sequence. The test was repeated when the participant failed to complete the sequence, lost his/ her balance, and touched the stick. The time for finishing the sequence was recorded as the score. The two best scores were recorded. ${ }^{[10]}$

Single leg balance test (SLBT): The SLBT, selected to test the static balance ability, is defined as standing on one foot with the contralateral knee bent and not touching the other leg. The individual is asked to maintain balance in the test position for $30 \mathrm{~s}$. The test is repeated with eyes opened and closed, and the last time is recorded. Scores under $30 \mathrm{~s}$ indicate decreased balance function. ${ }^{[10]}$

\section{Treatment program}

Following baseline assessments, all participants continued an outpatient rehabilitation program for 3 weeks, which included therapy units on 5 days per week. The conventional physical therapy (CPT) program comprised 20 mins of hot pack, 20 mins of Transcutaneous Electrical Nerve Stimulation, and 5 mins of ultrasound application to the neck and therapeutic exercises (ROM, posture, and isometric exercises). Therapeutic exercises were performed three times in a day as 10 sets. This rehabilitation protocol was the same for all patients in both groups. The participants of the study group underwent the GDRE program in addition to the CPT program for $10 \mathrm{~min}$ in each session. GDRE is a new practice used to improve the proprioception sense of cervical muscles and to rehabilitate patients with neck disability.

GRDE protocol: Small boxes numbered between 1 and 6 were ordered on a table $(1800 \mathrm{~mm} \times 400 \mathrm{~mm})$ with the same interval to divide five equal parts for 
GDRE. A researcher sits toward the table at a distance of $75 \mathrm{~cm}$. The patient sits behind the researcher at a distance of $75 \mathrm{~cm}$ and toward the table. The researcher looks at the boxes randomly with cervical rotations. The patient at the back should know which box the researcher looks at by saying the number of the box. ${ }^{[11]}$

After 3 weeks of the treatment program, participants in both groups were informed to continue the given exercise programs at home, and the participants were re-evaluated 3 weeks after discharge.

\section{Statistical analysis}

The statistical package SPSS 21.00 for Windows (SPSS Inc., Chicago, IL, USA) was used for statistical analysis. All continuous variables were evaluated for normality using Kolmogorov-Smirnov test. Continuous variables were expressed as mean \pm standard deviation. Since the groups don't show parametric characteristics, in terms of age and body mass index, Mann-Whitney U Test and balance, VAS, and neck disability results of the groups were compared via
Friedman variance analysis test. The level of significance was set at $p<0.05$.

\section{Results}

Demographic data for the study and control groups at baseline were compared and are summarized in Table 1 . There were no statistically significant differences between the groups.

The clinical outcomes of both groups are presented in Figure 2. The GRDE group tended to show higher SLBT with eyes opened $(p=0.010)$ and closed $(p=0.004)$ scores and lower neck pain intensity $(p=0.001)$, FSST scores $(p=0.001)$, and neck disability levels $(p=0.001)$ after the treatment. However, when the results of the tests before and after the treatment were examined, no significant differences were observed except in pain intensity scores in the control group ( $p>0.05$ ) (Table 2).

From the beginning of outpatient rehabilitation to 3 weeks follow-up, both groups showed a significant decrease in pain intensity $(p=0.003)$. Fur-

Table 1. Demographic characteristics of participants

\begin{tabular}{|c|c|c|c|}
\hline & $\begin{array}{c}\text { Mean } \pm \text { SD } \\
\text { Group I }\end{array}$ & $\begin{array}{c}\text { Mean } \pm \text { SD } \\
\text { Group II }\end{array}$ & $\mathbf{p}$ \\
\hline Age (years) & $43.95 \pm 7.14$ & $46.00 \pm 5.5$ & 0.371 \\
\hline \multirow[t]{2}{*}{ BMI $\left(\mathrm{kg} / \mathrm{m}^{2}\right)$} & $27.67 \pm 5.25$ & $29.16 \pm 3.88$ & 0.394 \\
\hline & n \% & $\mathrm{n} \%$ & \\
\hline \multicolumn{4}{|l|}{ Gender } \\
\hline Female & $16(80)$ & $16(80)$ & 0.653 \\
\hline Male & $4(20)$ & $4(20)$ & \\
\hline \multicolumn{4}{|l|}{ Occupation } \\
\hline Housewife & $10(50)$ & $13(65)$ & \\
\hline Retired & $1(5)$ & $2(10)$ & 0.393 \\
\hline Working & $9(45)$ & $5(25)$ & \\
\hline \multicolumn{4}{|l|}{ History of Medication } \\
\hline None & $10(50)$ & $11(55)$ & \\
\hline Use of drug & $3(15)$ & $3(15)$ & 0.436 \\
\hline Physiotherapy application & $6(30)$ & $4(20)$ & \\
\hline Surgical management & $1(5)$ & $2(10)$ & \\
\hline \multicolumn{4}{|l|}{ Habits of exercise } \\
\hline+ & $15(75)$ & $19(95)$ & 0.196 \\
\hline- & $5(25)$ & $1(5)$ & \\
\hline
\end{tabular}

BMI: Body mass index; SD: standard deviation. 


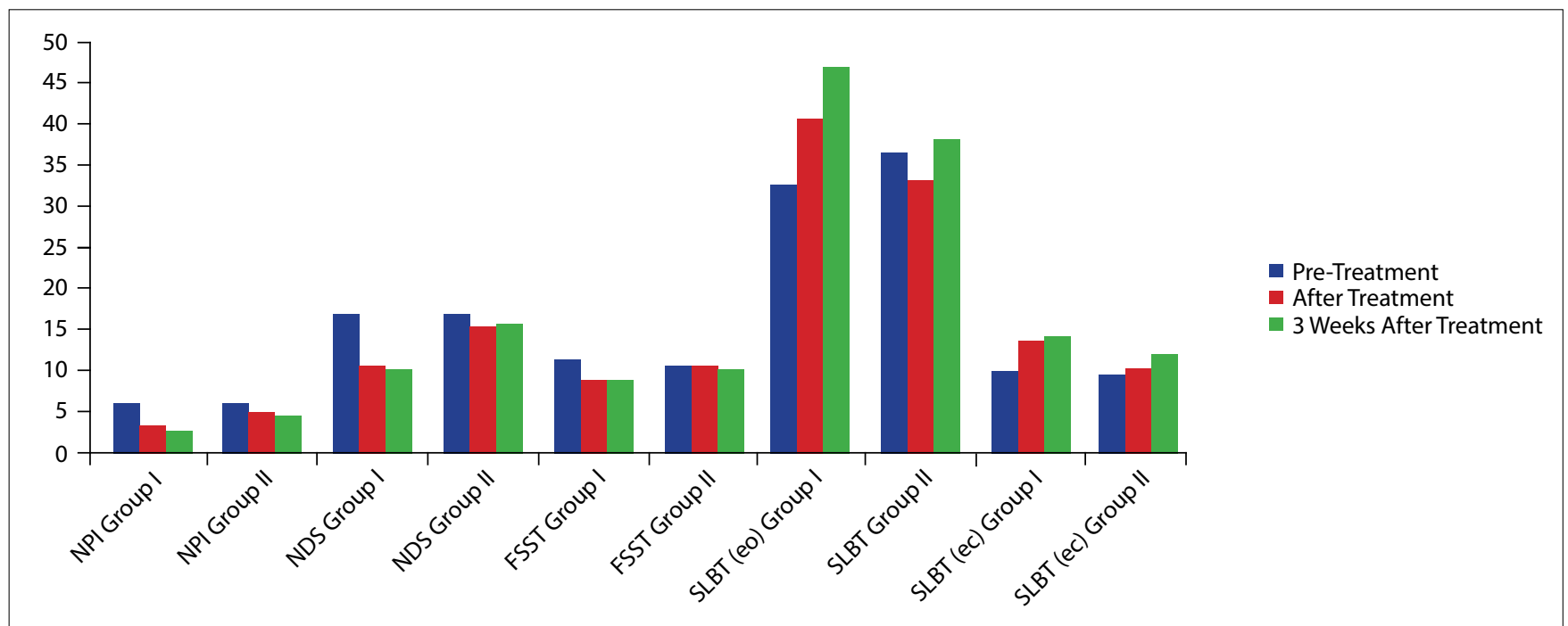

Figure 2. Clinical outcomes of both groups.

thermore, while neck disability levels $(p=0.001)$ and FSST $(p=0.001)$ scores showed significant decreases and SLBT with eyes opened $(p=0.001)$ and eyes closed $(p=0.004)$ scores showed significant increases in the GRDE group, pre- and post-treatment outcomes were similar in the control group ( $>0.05$ ) (Table 2).

Pre-treatment neck pain intensities, neck disability levels, and FSST and SLBT scores were similar in both groups ( $p>0.05$ ). Compared with the control group, a significantly greater decrease in neck pain intensities $(p=0.020)$, neck pain disability levels $(p=0.009)$, and FSST scores $(p=0.035)$ was observed in the GRDE group (Table 2). No significant difference was found between the groups with regard to SLBT scores ( $p>0.05$; Table 2). When follow-up scores were compared after 3 weeks scores, neck pain intensities $(p=0.001)$ and neck disability levels $(p=0.001)$ in the GRDE group were found to be significantly better than those in the control group.

\section{Discussion}

In our study investigating the effectiveness of proprioceptive training of the cervical region in patients with CNP, a significant decrease was observed in the neck pain intensity in both groups after 3 weeks of the rehabilitation program. Our results also allowed us to test whether dynamic proprioceptive training affects the neck disability level and balance. According to our results, proprioceptive exercises including GDRE, started to be used in the literature recently, in rehabilitation programs will have positive reflections on pain intensity, disability level, and balance in patients with CNP.

Examining the effects of cervical region injury, surgical intervention, and proprioceptively mediated activities in clinical assessment provides an understanding of the complexity of this system responsible for motor learning. ${ }^{[12]}$ As better understanding of the pain pathophysiology, the importance of preventive physiotherapy, particularly for neck health, started to be frequently emphasized. ${ }^{[13]}$ Abnormal cervical inputs observed as a result of pain, inflammation, changing muscle fiber sensitivity, and related changes lead to changes in sensorimotor arrangement and timing in patients with CNP. Therefore, the relationships among pain intensity, neck disability level, eye coordination, balance, and proprioception have been investigated in various studies. ${ }^{[14,15]}$

Because CNP may be observed due to various reasons related to sensorimotor impairment and one mode of exercise may not address all potential motor impairments from arising both the functional and structural changes, adequately. ${ }^{[16]}$ Traditional therapies are passive therapies; therefore, exercises that involve the active participation of patients for treatment have been investigated. ${ }^{[17]}$ When proprioceptors such as joints, muscle proprioceptors, and the golgi tendon organ are considered, ${ }^{[18]}$ the best applicationor active participation seems to be proprioceptive approaches. Jull et al. ${ }^{[19]}$ found that in patients with CNP, 3 weeks of proprioceptive training leads to greater improvement than craniosacral 
Table 2. Effect of both treatment programs on evaluation of parameters of groups

\begin{tabular}{|c|c|c|c|c|}
\hline Evaluation Parameters & Pre-Treatment & After Treatment & $\begin{array}{c}3 \text { Weeks After } \\
\text { Treatment }\end{array}$ & $\mathbf{p}$ \\
\hline Neck Pain Intensity (cm) (Group I) & $5.69 \pm 1.58$ & $3.22 \pm 1.79$ & $2.62 \pm 1.56$ & $\begin{array}{c}0.001^{*} \\
P_{1-2}=0.001^{* *} \\
P_{1-3}=0.003^{* *}\end{array}$ \\
\hline Neck Pain Intensity (cm) (Group II) & $5.70 \pm 1.47$ & $4.77 \pm 1.96$ & $4.01 \pm 1.51$ & $\begin{array}{c}0.017^{*} \\
P_{1-2}=0.032^{* *} \\
P_{1-3}=0.003^{* *}\end{array}$ \\
\hline p (Comparison Between Groups) & $0.841^{\dagger}$ & $0.020^{+}$ & $0.001^{+}$ & \\
\hline Neck Disability Scale Score (Group I) & $16.75 \pm 9.14$ & $10.55 \pm 7.33$ & $10.10 \pm 6.18$ & $\begin{array}{c}0.001^{*} \\
P_{1-2}=0.001^{* *} \\
P_{1-3}=0.001^{* *}\end{array}$ \\
\hline Neck Disability Scale Score (Group II) & $16.90 \pm 5.66$ & $15.30 \pm 5.68$ & $15.55 \pm 7.33$ & $0.055^{*}$ \\
\hline p (Comparison Between Groups) & $0.758^{+}$ & $0.009^{+}$ & $0.001^{+}$ & \\
\hline Four Step Square Test Score (s) (Group I) & $11.37 \pm 2.73$ & $8.69 \pm 1.88$ & $8.68 \pm 1.74$ & $\begin{array}{c}0.001^{*} \\
P_{1-2}=0.001^{* *} \\
P_{1-3}=0.001^{* *}\end{array}$ \\
\hline Four Step Square Test Score (s) (Group II) & $10.56 \pm 2.44$ & $10.45 \pm 2.94$ & $9.77 \pm 2.13$ & $0.247^{*}$ \\
\hline $\mathrm{p}$ (Comparison Between Groups) & 0.429 & $0.035^{+}$ & $0.085^{+}$ & \\
\hline $\begin{array}{l}\text { Single Leg Balance Test Score (with eyes } \\
\text { opened) (s) (Group I) }\end{array}$ & $32.17 \pm 20.92$ & $40.37 \pm 19.83$ & $46.61 \pm 18.28$ & $\begin{array}{c}0.001^{*} \\
P_{1-2}=0.010^{* *} \\
P_{1-3}=0.001^{* *}\end{array}$ \\
\hline $\begin{array}{l}\text { Single Leg Balance Test Score (with eyes } \\
\text { opened) (s)(Group II) }\end{array}$ & $35.98 \pm 17.64$ & $32.82 \pm 16.55$ & $37.89 \pm 17.37$ & $0.206^{*}$ \\
\hline p (Comparison Between Groups) & $0.512^{+}$ & $0.242^{+}$ & $0.091^{\dagger}$ & \\
\hline $\begin{array}{l}\text { Single Leg Balance Test Score (with eyes } \\
\text { closed) (s) (Group I) }\end{array}$ & $9.68 \pm 7.43$ & $13.51 \pm 10.37$ & $14.02 \pm 8.19$ & $\begin{array}{c}0.001^{*} \\
P_{1-2}=0.004^{* *} \\
P_{1-3}=0.004^{* *}\end{array}$ \\
\hline $\begin{array}{l}\text { Single Leg Balance Test Score (with eyes } \\
\text { closed) (s) (Group II) }\end{array}$ & $9.42 \pm 7.47$ & $10.16 \pm 6.47$ & $11.74 \pm 6.56$ & $0.101^{*}$ \\
\hline p (Comparison Between Groups) & $0.947^{\dagger}$ & $0.414^{\dagger}$ & $0.289^{\dagger}$ & \\
\hline
\end{tabular}

${ }^{*}$ Friedman Analysis of Variance; ${ }^{* *}$ Wilcoxon signed-rank test; ${ }^{+}$: Mann-Whitney $\mathrm{U}$ test; $\mathrm{P}_{1-2}=\mathrm{p}$ value for comparison of pre- and after treatment scores; $\mathrm{P}_{1-3}=\mathrm{p}$ value for comparison of scores of pre-treatment and 3 weeks after treatment.

therapy in joint positioning, neck pain, and neck disability perception. In a review, it was also stated that there is not enough evidence regarding whether the addition of proprioceptive training to CPT in patients with CNP reduces pain and increases functionality. ${ }^{[20]}$ In our study, it was clearly shown that both interventions result in a reduction in pain, but CPT had no effect on disability perception dynamics and static balance in patients with CNP.

CPT combined with proprioceptive training may be useful for improvements in motor control and bal- ance. However, studies investigating the effect of exercise on motor performance show somewhat conflicting results. ${ }^{[20]}$ This contradiction may be because patients participating in the studies were heterogeneous. It can be thought to be the main reason for this heterogeneity that patients with CNP may not be aware of their need for treatment because dizziness does not accompany other symptoms and balance problems cannot be recognized by the patient. ${ }^{[17]}$ It has been reported that improvements in motor performance require exercise protocol including proprioceptive training for neck problems. ${ }^{[20]}$ Ahmed 
et al. ${ }^{[12]}$ and Pettorossi et al. ${ }^{[21]}$ clearly found that the recovery of proprioceptive disabilities improves balance, locomotion, cervical kinesthetic sensitivity, body orientation, and self-motion perception in patients with CNP. In accordance with these studies, the present study demonstrates that cervical proprioception training not only decreases pain intensity but also has an effect on static and dynamic balance.

\section{Limitations}

The limitations of our study include the relatively small sample size, short treatment duration to determine the effectiveness of GDRE, and the inability to assess the long-term (at least 3 months) effects after the treatment. However, the similarity between the groups in terms of demographic characteristics, medical support, exercise habit, and test values before the treatment strengthened our results. We believe that our results will shed light on future studies by increasing awareness about chronic cervical pain management. We anticipate the need for studies investigating the effectiveness of proprioceptive exercises for the neck have larger sample and long term treatment.

\section{Conclusion}

In conclusion, the present study highlights the positive effects of GDRE for proprioceptive training on balance. Whereas dynamic and static balance improves with the addition of cervical muscle proprioceptive training to CPT, pain intensity decreases with both CPT and proprioceptive training. Improving the position sense of cervical muscles protects against the loss of balance. The acquisition of the correct neck proprioception sense must be one of the primary purposes of rehabilitation in patients with neck disability. New experimental protocols based on these findings can open new avenues in the investigation of the effect of neck proprioceptive training on balance and locomotion.

\section{Conflict-of-interest issues regarding the authorship or article: None declared.}

\section{Peer-rewiew: Externally peer-reviewed.}

\section{References}

1. Falla $D$, Lindstrøm R, Rechter $L$, Boudreau S, Petzke F. Effectiveness of an 8-week exercise programme on pain and specificity of neck muscle activity in patients with chronic neck pain: a randomized controlled study. Eur J Pain 2013;17(10):1517-28. [CrossRef]

2. Gross AR, Paquin JP, Dupont G, Blanchette $S$, Lalonde $P$, Cristie $T$, et al. Exercises for mechanical neck disorders: $A$ Cochrane review update. Man Ther 2016;24:25-45. [CrossRef]

3. Gross A, Langevin P, Burnie SJ, Bédard-Brochu MS, Empey $B$, Dugas $E$, et al. Manipulation and mobilisation for neck pain contrasted against an inactive control or another active treatment. Cochrane Database Syst Rev 2015;(9):CD004249. [CrossRef]

4. Kroeling P, Gross A, Graham N, Burnie SJ, Szeto G, Goldsmith $\mathrm{CH}$, et al. Electrotherapy for neck pain. Cochrane Database Syst Rev 2013;(8):CD004251. [CrossRef]

5. Mousavi-Khatir R, Talebian S, Maroufi N, Olyaei GR. Effect of static neck flexion in cervical flexion-relaxation phenomenon in healthy males and females. J Bodyw MovTher 2016;20(2):235-42. [CrossRef]

6. Lafond D, Champagne A, Cadieux R, Descarreaux M. Rehabilitation program for traumatic chronic cervical pain associated with unsteadiness: a single case study. Chiropr Osteopat 2008;16:15. [CrossRef]

7. Treleaven J, Chen X, Sarig Bahat H. Factors associated with cervical kinematic impairments in patients with neck pain. Man Ther 2016;22:109-15. [CrossRef]

8. Yousif N, Cole J, Rothwell J, Diedrichsen J. Proprioception in motor learning: lessons from a deafferented subject. Exp Brain Res 2015;233(8):2449-59. [CrossRef]

9. Aslan E, Karaduman A, Yakut Y, Aras B, Simsek IE, Yagli N. The cultural adaptation, reliability and validity of neck disability index in patients with neck pain: a Turkish version study. Spine (Phila Pa 1976) 2008;33(11):E362-5. [CrossRef]

10. Isık El, Altug F, Cavlak E. Reliability and validity of four step square in older adults. Turkish Journal of Geriatrics 2015;18(2):151-5.

11. Nobusako S, Matsuo A, Morioka S. Effectiveness of the gaze direction recognition task for chronic neck pain and cervical range of motion: a randomized controlled pilot study. Rehabil Res Pract 2012;2012:570387. [CrossRef]

12. Pettorossi VE, Schieppati M. Neck proprioception shapes body orientation and perception of motion. Front Hum Neurosci 2014;8:895. [CrossRef]

13. Horn ME, Brennan GP, George SZ, Harman JS, Bishop MD. A value proposition for early physical therapist management of neck pain: a retrospective cohort analysis. BMC Health Serv Res 2016;16:253. [CrossRef]

14. Meisingset I, Woodhouse A, Stensdotter AK, Stavdahl $\varnothing$, Lorås $\mathrm{H}$, Gismervik $\mathrm{S}$, et al. Evidence for a general stiffening motor control pattern in neck pain: a cross sectional study. BMC Musculoskelet Disord 2015;16:56. [CrossRef]

15. Treleaven J. Sensorimotor disturbances in neck disorders affecting postural stability, head and eye movement controlPart 2: case studies. Man Ther 2008;13(3):266-75. [CrossRef]

16. O'Leary S, Jull G, Kim M, Uthaikhup S, Vicenzino B. Training mode-dependent changes in motor performance in neck pain. Arch Phys Med Rehabil 2012;93(7):1225-33. [CrossRef]

17. Röijezon U, Björklund $M$, Bergenheim $M$, Djupsjöbacka $M$. A novel method for neck coordination exercise--a pilot 
study on persons with chronic non-specific neck pain. J Neuroeng Rehabil 2008;5:36. [CrossRef]

18. Poliak S, Norovich AL, Yamagata M, Sanes JR, Jessell TM. Muscle-type Identity of Proprioceptors Specified by Spatially Restricted Signals from Limb Mesenchyme. Cell 2016;164(3):512-25. [CrossRef]

19. Jull G, Falla D, Treleaven J, Hodges P, Vicenzino B. Retraining cervical joint position sense: the effect of two exercise regimes. J Orthop Res 2007;25(3):404-12. [CrossRef]
20. McCaskey MA, Schuster-Amft C, Wirth B, Suica Z, de Bruin ED. Effects of proprioceptive exercises on pain and function in chronic neck- and low back pain rehabilitation: a systematic literature review. BMC Musculoskelet Disord 2014;15:382. [CrossRef]

21. Atya AM, Ahmed GM. Effectiveness of Physical Therapy Intervention on Neck Proprioception and Balance Parameters in Patients With Chronic Mechanical Neck Pain. Bulletin of Faculty of Physical Therapy 2009;4(2):41-7. 